\title{
Participation of Women in Fisheries: A Study on Gender Issues in Manipur, India
}

\author{
Waikhom Tomthinnganba Meetei, Biswarup Saha* and Prasenjit Pal
}

Dept. of Extension and Social Sciences, College of Fisheries, Central Agricultural University (Imphal), Tripura (799 210), India

\section{Article History}

Manuscript No. AR1589

Received in $30^{\text {th }}$ April, 2016

Received in revised form $22^{\text {nd }}$ June, 2016

Accepted in final form $14^{\text {th }}$ July, 2016

\section{Correspondence to}

${ }^{*}$ E-mail: biswarup.ext@gmail.com

\section{Keywords}

Women participation, women empowerment, fisheries activities, constraints, issues

\begin{abstract}
Conscious efforts to address the gender issues in fisheries sector and the involvement of more women through explicit support to their participation are yet to be undertaken intensively in North Eastern region of India. Therefore, the study was conducted to know the level of participation of women in fisheries activities in Manipur and to identify the different constraints perceived by them while participating in fisheries activities. One hundred and twenty women who were involved in different fisheries activities formed the sample of the study. A semi-structured interview schedule was used to collect the information through personal interview. The data was analyzed by using frequency, percentage, 'Z' test. Empowerment index was also developed for the study to know the level of empowerment after participation in fisheries activities. The participation of women was found maximum in aspects of capture fisheries, followed by post harvesting, marketing of fishes and stocking of fish seeds. Most significant participation under the post harvesting practices was value addition (3.40), cleaning and grading (3.40) and transporting (2.93). The ' $\mathrm{Z}$ ' values revealed that, there was significant difference in index values of empowerment of rural women before and after taking up fisheries activity, which clearly revealed the fact that participation in fisheries activity significantly contributed for enhancement in empowerment. Lack of access and control over resources (1.80), low access to credit (1.74), lack of confident in technical issues (1.60), lack of women friendly aquaculture technology (1.50) were the major constraints identified in empowerment of women through participation in fisheries activities.
\end{abstract}

\section{Introduction}

Women are the most undervalued and inappropriately utilized human resource in the developing world. With the global efforts to increase gender awareness, noticeable changes in the attitude of people towards using this un-utilized/underutilized human capacity have been seen in the last decade (Nandeesha, 2001). According to World Bank report (1986), "Women are central to the success of poverty alleviation efforts in the short, medium and in the long run". Empowerment as a concept was introduced at the International Women's Conference in 1985 at Nairobi. The Conference defined empowerment as a "redistribution of social power and control of resources in favour of women". Women development in recent years emphasized on providing equal opportunities to women by removing gender bias, empowering women and creating self-reliance among them. Empowerment of women and gender equality recognized globally as a key element to achieve progress in all areas. It is one of the eight millennium goals to which world leaders agreed at the Millennium
Summit held at New York in 2000. Over the past few years, the word "Empowerment" has become the buzzword in rural development in India and the year 2001 was declared as the 'women's empowerment year' by the Government of India. Globally, the role of women and the need to consider gender issues in aquaculture development was first recognized by the FAO-NORAD sponsored workshop on "Women in Aquaculture" in 1987 (Nash et al., 1987). In this workshop, the scope to productively engage women in aquaculture and help them to be important contributors to family economy was examined. The workshop recognized that aquaculture being not a labour intensive industry, the opportunity to employ more women in the sector is limited. However, the economic benefits of the fisheries sector being higher than most other agricultural crops, it was recognized that targeting women could bring multifarious benefits. Provision of required skills to women to carry out the activity and making available adequate credit to carry out the activity were identified as the most important components to trigger aquaculture development through 
the active participation of women. This global workshop recognized the need to influence policies to be gender sensitive from the early stage since aquaculture is in developing stage in many countries. However, conscious efforts to address the gender issues in aquaculture sector and involve more women through explicit support to their participation are yet to be undertaken intensively.

Manipur is a land-locked hilly state in the northeastern part of India bordering Myanmar and is known for its rich fisheries resources through the well-known Loktak Lake (included under Ramsar Convention) along with several other forms of fresh water resources. It is situated between $23^{\circ} 83^{\prime} \mathrm{N}$ and $25^{\circ} 68^{\prime}$ $\mathrm{N}$ latitude and between $93^{\circ} 02^{\prime} \mathrm{E}$ and $94^{\circ} 98^{\prime} \mathrm{E}$ longitude, at an altitude of $790 \mathrm{~m}$ above mean sea level. The state has a distinct zoo-geographical identity. The total area of the state is $22,327 \mathrm{~km}^{2}$ with hilly areas covering about $92 \%$ of the landscape that enclose a central valley of about $1,800 \mathrm{~km}^{2}$. The Meitei community and the tribal population are indigenous to this region. The Meitei community, being largely the plain dwellers, inhabits the valley, while other tribes like Nagas and Kukis live largely in the hills. Fish have always played a central role in Manipuri socio-economic culture and over a period of time several customs and beliefs have evolved and passed on from generation to generation. The role of women is well recognized in the state of Manipur, and their contribution to the economy is increasing significantly (Gurumayum et al. 2004). Although women are reportedly better placed in this valley as compared to the other parts of India, there are many issues that need to be addressed to improve their involvement in fisheries activities. Gender issues assume great importance in Indian agricultural scenario due to the large diversity in the status of women which is influenced mostly by social and religious taboos, economic status and farm production systems. Hence, issues relating to both research coverage and impact in terms of gender need careful study. However, the women contribution to the family economy is yet to be evaluated. Review on women involvement in fisheries sector reflects that despite their contribution in the fishing sector, women's operations are often small-scale and their incomes are low as compared to those of their male counterparts. They face various constraints, including suitable technology credit and finance problems, a lack of training, inadequate markets and transport problems. Therefore, promotion of the full participation and empowerment of women in the fisheries sector need to be recognized widely with effective support systems. When the United Nations declared the Decade for Women in 1975, an important step should be taken to raise the profile of the ageold social, cultural and economic barriers that prevented and hindered women from being active agents and beneficiaries of development. This will necessitate a changing of the current nature of both women's participation in fisheries as well as associated issues, such as its impact on their empowerment. This paper therefore aims to determine the level of participation of women in fisheries activities and the extent of women empowerment through participation in fisheries activities. The study further focuses on various gender issues related to the participation of women in fisheries activities.

\section{Materials and Methods}

\subsection{Study area and sampling techniques}

The study was undertaken in the year 2014. Ex-post facto research design was used for conducting the study. Bishnupur district was selected purposively because of highest production among all the districts in the state coupled with the presence of Loktak Lake in the district which is one the most important source of fish production of the state. All the three subdivisions were included in the study to make the study more comprehensive in nature. Four villages from each sub-division were selected purposively based on fisheries resources and women involvement in fisheries. Thus, a total of 12 villages were selected. All the women engaged in aquaculture activities for more than 3 years in all the twelve villages were the universe of the present study. From each village 10 women who have the experience in aquaculture activities around 3 years were selected through simple random sampling (without replacement) method. Thus a total of 120 women were selected for the study.

\subsection{Method of data collection}

In order to collect the data required for the study, a structured interview schedule was developed. The draft interview schedule was tested in a small subsample of 30 women in the study area. The interview schedule was then modified as a result of feedback from this test. Test-retest reliability was conducted to determine the reliability of the components of the survey (the reliability coefficient ranged from 0.68 to 0.79 ) and a number of referees from relevant disciplines were employed to check the content validity of the questionnaire. Data were collected from the sampled rural women during the months of February to April, 2014 via face-to-face interviews.

\subsection{Measurement of women empowerment}

A large number of studies are available on empowerment measuring techniques. After a careful study of the available literature (Stromquist 1995; Jejeebhoy 1995; CIDA 1996; Kishor 2000; Biswas 2002; Bharathamma 2005; Rahman and Naoroze 2007 and Suresh 2008) five measures of empowerment were selected for this study in the line of Rahman and Naozore (2007). These are; a woman's decision making ability within the family, spending ability, cosmopoliteness, social participation and access to assets and resources. A number of items were 
arranged under each of these five measurements and the women taking part in the survey were asked to indicate their perceived extent of empowerment along a 4-point continuum, taking into account their situations influenced by fisheries activities. The twelve items included for measuring the women's decisionmaking ability within a family are: the education of children, family health issues, the celebration of social and religious events, choice of guests and entertainment at social functions, selecting and using family planning methods, giving loans to others, fisheries production, fish marketing and purchasing of inputs, constructing and repairing of houses, and daily family household expenditure, addressing social issues and problems, women's rights and equity in the community.

The spending ability of a woman was measured by ten points related to the ability of her financial authority. These include: buying household furniture, and other items, providing financial help to others, expenditure on medicare and health, buying gifts for social functions, making donations to charity, lending and borrowing money, spending money on income generating activities, spending income from family sources, purchasing and selling of land and other assets, and spending money on children's education. The cosmopoliteness of a woman was defined as her general orientation outside her close social system (Hossain, 1992). A social system was taken to be 'any social structure composed of social interactions and cultural factors, in which the members interact more with members than with non-members when participating in the organization as an on-going concern'(Loomis and Beegle 1957). A respondent's cosmopoliteness was measured by adding up eight items as the number of times she reportedly having visited the market place, friends and relatives houses outside the home village, the upazila (sub-district) headquarters, the neighboring upazilas, the local district headquarters, other districts, the capital city and the local fisheries office. Social participation include seven social and community activities, namely; participation in social functions such as marriage and birthday celebrations, helping neighbors in crisis situations, working with people in emergency situations (such as natural disasters), participation in village meetings and arbitrations, participation and organization of cultural programs, arbitration in the conflicts of neighbors and family, and casting votes in local and national elections without outside interference. Access to assets and resources include the following seven items; access to a bank (e.g. having their own bank account), access to institutional credit, ability to contact public services (health, nutrition, farming etc.), access to family income and resources, access to valuable instruments and machinery, access to farm management and budgeting, and access to inherited properties. The empowerment score of a respondent in a particular measure of empowerment was computed by adding the scores obtained in all items in that class. A summary of the measuring system of all five measures of empowerment is presented in Table 1.

\begin{tabular}{|c|c|c|c|}
\hline $\begin{array}{l}\text { Empower- } \\
\text { ment } \\
\text { dimensions }\end{array}$ & $\begin{array}{c}\text { Items } \\
\text { used }\end{array}$ & $\begin{array}{c}\text { Responses and assigned } \\
\text { scores }\end{array}$ & $\begin{array}{l}\text { Possible } \\
\text { score } \\
\text { range }\end{array}$ \\
\hline $\begin{array}{l}\text { Decision } \\
\text { making abil- } \\
\text { ity in family }\end{array}$ & 12 & $\begin{array}{l}\text { Full influence (3), Moderate } \\
\text { influence (2), low influence } \\
\text { (1), No influence (0) }\end{array}$ & $0-36$ \\
\hline $\begin{array}{l}\text { Spending } \\
\text { ability }\end{array}$ & 10 & $\begin{array}{l}\text { Full ability (3), Partial } \\
\text { ability (2), low ability (1), } \\
\text { No ability (0) }\end{array}$ & $0-30$ \\
\hline $\begin{array}{l}\text { Cosmo } \\
\text { politeness }\end{array}$ & 8 & $\begin{array}{l}\text { Frequently (3), Occasionally } \\
\text { (2), Rarely (1), Not at all (0) }\end{array}$ & $0-24$ \\
\hline $\begin{array}{l}\text { Social } \\
\text { participation }\end{array}$ & 7 & $\begin{array}{l}\text { Frequently participation (3), } \\
\text { Occasionally participation } \\
\text { (2), Seldom participation } \\
\text { (1), No participation (0) }\end{array}$ & $0-21$ \\
\hline $\begin{array}{l}\text { Access to } \\
\text { assets and } \\
\text { resources }\end{array}$ & 7 & $\begin{array}{l}\text { Full access (3), Partial } \\
\text { access (2), Low access (1), } \\
\text { No access (0) }\end{array}$ & $0-21$ \\
\hline
\end{tabular}

The overall empowerment score of a respondent was determined by adding the total scores from all five components, which is range from 0 to 132, with 0 indicating no empowerment and 132 indicating the highest level of empowerment. In order to make a comparison among the five measures of empowerment, a unit score will be computed for each using the following formula:

Unit empowerment score $=\frac{\begin{array}{l}\text { Mean score of aparticular } \\ \text { dimension }\end{array}}{\begin{array}{l}\text { Maximum possible score } \\ \text { of the dimension }\end{array}}$

Based on the score obtained from these variables extent of empowerment was calculated by computing the empowerment index (expressed in percentage) as follows. Empowerment Index

Empowerment index $=\frac{\text { Score obtained }}{\text { Maximum obtainable score }} \times 100$

Change in empowerment index through involving in fisheries activities were measured as

$\begin{aligned} & \text { Average gain in } \\ & \text { Empowerment index }\end{aligned}=\frac{\begin{array}{l}\text { Difference of score as } \\ \text { (after-before) }\end{array}}{\begin{array}{l}\text { Maximum score to } \\ \text { be obtained }\end{array}} \times 100$

\subsection{Measurement of women participation}

Participation refers to extent of engagement of rural women in different activities related to fisheries. The participation of women in the fisheries activities from production to marketing and fishing will be grouped in certain number based on 
discussion and pilot survey to the study area. The aggregate participation score of each respondent will be obtained by adding the respective score for each item. A 4-point rated scale will be used where a respondent will be asked to indicate her extent of participation in a particular fisheries activity. The possible scores are 1 for 'no participation,' 2 for 'rare participation,' 3 for 'occasional participation' and 4 for 'frequent participation.' The total participation score of a rural woman will be obtained by summing her scores in all the selected fisheries activities. Based on the responses of the respondents the frequencies and percentages will be calculated. Maximum score obtained by respondents will indicate higher participation in different fisheries activities. A participation index was used to measure the participation of women in different areas of fisheries and aquaculture activities. The index was constructed using a 3 point Likert scale after (Ayoade et al., 2009). Participation was measured on scale 1-4 in order of importance from; rarely involved $=1-1.99$, occasionally involved $=2-2.99$, regularly involved $=3-3.99$. The respondents were asked to indicate their level of participation in 30 practices involved in fisheries and aquaculture. The mean score for each of the practices/activities was calculated and the grand mean score of all the practices was divided by the number of activities to determine the level of participation of women in the study area.

\subsection{Measurement of constraints}

The constraints in the present study refer to all those factors or forces which hinder or restrict the empowerment process of women in the study area. For that a schedule was developed which is present in Appendix. There were twelve statements in the schedule which were determined by pertinent literature, personal experience, discussions held with the experts. These statements were assigned $0,1,2$ score as not serious, serious or very serious respectively. The total score for each constraint was calculated with the help of the responses received from all 120 respondents. The mean score for a particular constraint was worked out by dividing with the weighted score of the constraints with the total number of respondents. Afterwards, the ranking of constraints was done according to mean score of each statement.

\subsection{Statistical analysis}

Besides the conventional statistical measures such as mean, standard deviation and percentage, a number of tests were performed. Wilcoxon signed Rank Test $(Z)$ was used to know the significance of difference in empowerment before and after participating in fisheries activity. The chi-square analysis was also used to find the association between empowerment and level of participation of respondents.

\section{Results and Discussion}

3.1. Level of participation of women in different areas of

\section{fisheries}

In most parts of India, women are largely confined to household activities. However, in Manipur, both in the rich and poor households, women were found to engage in fieldbased supportive activities like agriculture and fisheries. The fisheries activities in Manipur were seen largely dominated by women. They play multiple roles; apart from the traditional role of managing household activities from cooking to taking care of the elders and children in the family, they were found to involve in outdoor-related tasks. The many water bodies in the valley provide a wealth of fishery resources and a variety of aquatic plants that are used as food by the people. Women were seen to involve in capture as well as culture fisheries, fish processing, fish marketing and fish transportation. During the season when fish are available in abundance, women spend several nights working to preserve them in various forms for use during the off-season. Hence, women participation in different areas of fisheries was worked out and the score are classified accordingly as shown in Table 2. In view of that, majority of the women (75\%) had medium level (73.8-88.8) of participation whereas, $12.5 \%$ had both low (less than 73 ) and high (more than 88.8) level each as obtainable ${ }^{-1}$ participation

Table 2: Classification of women based on participation in fisheries activities

\begin{tabular}{lcccc}
\hline Participation score & Frequency & $\begin{array}{c}\text { Percentage } \\
(\%)\end{array}$ & Mean & SD \\
\hline $\begin{array}{l}\text { Low Participation } \\
\text { (less than 73) }\end{array}$ & 15 & 12.5 & 80.98 & 7.98 \\
$\begin{array}{l}\text { Medium Partici- } \\
\text { pation (73-88.8) }\end{array}$ & 90 & 75 & & \\
$\begin{array}{l}\text { High Participation } \\
\text { (more than 88.8) }\end{array}$ & 15 & 12.5 & & \\
\hline
\end{tabular}

scores. Further, the nature of involvement of women in capture and culture fisheries were studied and presented in the Table 3. Active participation of women in only culture $(65 \%)$, and both capture and culture (35\%) fisheries were observed. In the capture fisheries sector, activities that do not require great strength like the use of the Chinese dip net, push net and traps are operated by women. In the aquaculture sector, which is now emerging as a major activity, participation of women in all stages of aquaculture was noticed. The result is in conformity with the findings of (Gurumayum et al., 2004).

\subsection{Distribution of farm women according to their aspect}

\begin{tabular}{|c|c|c|c|}
\hline Sl. No. & Nature of involvement & Frequency & Percentage \\
\hline 1. & Only culture fisheries & 78 & 65.0 \\
\hline 2. & Both capture+culture & 42 & 35.0 \\
\hline
\end{tabular}


wise participation in fisheries

Table 4 presents the aspect wise participations of farm women in fisheries and aquaculture. It reveals that the participation of farm women was maximum (as per of weight age) in aspects

\begin{tabular}{|c|c|c|c|c|c|c|c|}
\hline Sl. No. & Aspect & No & Rare & Occasional & Regular & Mean & Rank \\
\hline 1. & Pond preparation & & & & & 2.39 & VIII \\
\hline a. & Site selection & $13(10.8)$ & $44(36.7)$ & $63(52.5)$ & $0(0.0)$ & & \\
\hline b. & Designing & $15(12.5)$ & $71(59.2)$ & $29(24.2)$ & $5(4.2)$ & & \\
\hline c. & Dyke construction and maintenance & $8(6.7)$ & $63(52.5)$ & $43(35.8)$ & $6(5.0)$ & & \\
\hline d. & Water harvesting & $0(0.0)$ & $69(57.5)$ & $43(35.8)$ & $8(6.7)$ & & \\
\hline e. & Pond renovation & $6(5.0)$ & $57(47.5)$ & $55(45.8)$ & $2(1.7)$ & & \\
\hline 2. & Pre-stocking management & & & & & 2.47 & VI \\
\hline a. & Eradication of unwanted fish/weed/animals & $0(0.0)$ & $54(45.0)$ & $57(47.5)$ & $9(7.5)$ & & \\
\hline b. & Fertilization of ponds & $0(0.0)$ & $36(30.0)$ & $75(62.5)$ & $9(7.5)$ & & \\
\hline c. & Liming & $2(1.7)$ & $70(58.3)$ & $38(31.7)$ & $10(8.3)$ & & \\
\hline d. & Fish seed production & $22(18.3)$ & $76(63.3)$ & $22(18.3)$ & $0(0.0)$ & & \\
\hline 3. & Stocking of rearing and grow out ponds & & & & & 2.75 & IV \\
\hline a. & Selection and purchase of suitable fish species & $1(0.8)$ & $43(35.8)$ & $75(62.5)$ & $1(0.8)$ & & \\
\hline b. & Carrying the species & $0(0.0)$ & $43(35.8)$ & $72(60.0)$ & $5(4.2)$ & & \\
\hline c. & Releasing & $1(0.8)$ & $31(25.8)$ & $64(53.3)$ & $24(20.0)$ & & \\
\hline 4. & Post-stocking management & & & & & 2.49 & V \\
\hline a. & Feed preparation & $7(5.8)$ & $54(45.0)$ & $58(48.3)$ & $1(0.8)$ & & \\
\hline b. & Feeding & $4(3.3)$ & $45(37.5)$ & $58(48.3)$ & $13(10.8)$ & & \\
\hline c. & Precaution and preventive measures for diseases & $2(1.7)$ & $79(65.8)$ & $38(31.7)$ & $1(0.8)$ & & \\
\hline d. & Pond environment Monitoring & $2(1.7)$ & $52(43.3)$ & $63(52.5)$ & $3(2.5)$ & & \\
\hline e. & Fish health monitoring & $5(4.2)$ & $60(50.0)$ & $49(40.8)$ & $6(5.0)$ & & \\
\hline f. & Management of common hazards & $7(5.8)$ & $72(60.0)$ & $40(33.3)$ & $1(0.8)$ & & \\
\hline 5. & Harvesting & & & & & 2.46 & VII \\
\hline a. & Application of proper gear and crafts & $5(4.2)$ & $29(24.2)$ & $59(49.2)$ & $27(22.5)$ & & \\
\hline b. & Managing the gear and crafts & $0(0.0)$ & $53(44.2)$ & $53(43.3)$ & $15(12.5)$ & & \\
\hline 6. & Post harvesting & & & & & 3.00 & II \\
\hline a. & Cleaning and grading & $2(1.7)$ & $15(12.5)$ & $50(41.7)$ & $53(44.2)$ & & \\
\hline b. & Preservation & $10(8.3)$ & $66(55.0)$ & $31(25.8)$ & $13(10.8)$ & & \\
\hline c. & Transport & $0(0.0)$ & $27(22.7)$ & $74(61.7)$ & $19(15.8)$ & & \\
\hline d. & Value addition & $2(1.7)$ & $15(12.5)$ & $36(30.0)$ & $67(55.8)$ & & \\
\hline 7. & Marketing & & & & & 2.79 & III \\
\hline a. & Marketing of table size fish & $2(1.7)$ & $44(36.7)$ & $57(47.5)$ & $17(14.2)$ & & \\
\hline b. & Marketing of fish products & $0(0.0)$ & $40(33.3)$ & $56(46.7)$ & $24(20.0)$ & & \\
\hline c. & Marketing of inputs & $0(0.0)$ & $46(38.3)$ & $56(46.7)$ & $18(15.0)$ & & \\
\hline 8. & Fishing & & & & & 3.41 & I \\
\hline a. & Managing and look after the gear & $1(0.8)$ & $14(11.7)$ & $33(27.5)$ & $72(60.0)$ & & \\
\hline b. & Trap & $0(0.0)$ & $3(2.5)$ & $46(38.3)$ & $71(59.2)$ & & \\
\hline c. & Hook & $2(1.7)$ & $25(20.8)$ & $41(34.2)$ & $52(43.3)$ & & \\
\hline
\end{tabular}

Data in the parentheses reflects the percentage 
of capture fisheries (rank I), followed by post harvesting (rank II), marketing of fishes (rank III) and stocking (rank IV). Least participation of farm women was observed in pond preparation and harvesting in aquaculture. This might be due to the fact that males are dominating in these activities and there is lack of women friendly technologies associated with these.

It is experienced from the study that the contributions of women in fisheries activities in Manipur are remarkable. They play multiple roles; apart from the traditional role of managing household activities from cooking to taking care of the elders and children in the family, they were involved in outdoor-related tasks. The many water bodies in the valley provide a wealth of fishery resources and a variety of aquatic plants that are used as food by the people. Women are involved in capture and culture fisheries, fish processing, fish marketing and fish transport. During the season when fish are available in abundance, women spend several nights working to preserve them in various forms for use during the off-season. The findings support the observation of Nandeesha and Hanglomong (1997). They also reported that the role of women in fisheries activities in Manipur reflects the situation in Cambodia.

Active involvement of women in fishing was observed in the study area using various types of fishing gears that can be easily operated by them. Chinese dip nets were most commonly used by women to collect fish from areas where these are reasonably abundant. Women were also involved in handpicking different types of snails. Different types of bamboo traps are also used for collecting fish and other animals from the water. Fishing in ponds using a scoop net or drag net was also common. The women were largely involved in managing and look after the gears such as cleaning, drying, storing, repairing etc.

Aquaculture is a major activity carried out in the state and women are most actively involved in it. Involvement of women in all stages of aquaculture is a common phenomenon observed throughout the state. Integrated aquaculture like fish culture in paddy fields, integration of animals with fish culture and horticulture were found to be commonly practiced. Digging ponds along with men, preparing ponds for stocking fish seed, procurement of seed, routine pond management like fertilization, feeding, harvesting fish, and marketing of harvested fish were carried out by women along with men. Buying and stocking fingerlings were important technical decisions that few women were involved in. However, the role of men focused more on decision making on matters such as fish species, purchasing, netting, harvesting while women provided the labour for preparing the feed and feeding of fish on a daily basis and marketing.

Recognizing the interest of women in aquaculture and the hardship confronted by them, women's associations, such as the nupi ngayok marup (Women Fish Culture Group), have been established. In the state, there are now 696 such groups that undertake fish culture activity with the support of the department of fisheries (DOF). The members of the organization are provided with fish seed from the DOF on a credit basis, and the payment is made to the DOF after the harvest of fish. The scheme which started in 1983 has been quite successful in introducing improved methods of fish culture (Nandeesha, 2009). Fish ponds are commonly seen in homes in the Manipur Valley. In places where there is no drinking water supply system, families maintain two ponds-one to meet family water necessities and another to culture fish.

Unlike in other places where men play key roles in transportation of fish and women in marketing, in Manipur, women carry out both activities efficiently. Although men do assist in large-scale operations, in general women independently undertake the smaller-scale activities, thereby allowing men to attend to other tasks. Fish marketing is generally undertaken by women and is a major domain of women in the retail trade sector. There are markets that are known as Nupi Keithels or Ema Keithels, which means women's or mother's market, and only women are allowed to trade in these markets. (Gurumayum et al., 2004) in this connection reported that in the central market of Imphal, there are about 300 women fish traders. All these women are allocated a regular trading place by the municipal Council on a rental basis. Women come to the market very early in the morning, after collecting fish from the farmers. As women are involved with fish trading during the major part of the day, they are hard pressed for time to accomplish other activities. Ikiara (1999) reported that women dominate the fish marketing system of Lake Victoria while men dominate its production. Women are found wholesaling and retailing fish. As wholesalers, they purchase fish in bulk from fishers or from co-operative societies and sell it to retailers. As retailers, women purchase their fish from wholesalers and transport it to their selling points. Women face enormous problems in the transportation of fish in the early hours of the day. The most severe problem is frequent strikes by various groups which result in the loss of several days a month. With no trading on strike days, women face severe hardship. With no cold storage facilities in place, women are not able to preserve fish. Women expressed the need for cold storage and ice production facilities. Improving the hygienic condition of the market is also essential.

Fish processing is usually categorised as full processing or semi-processing. Women in the study area were usually involved in semi-processing due to the huge capital investment that is required in full processing. Fish is either sold fresh or in a processed state. Processing is done to preserve and improve the flavour of the fish. Processing involves smoking, sun drying or frying. There is a greater diversity of products in the market. 
3.3. Participation index result of women in different fisheries and aquaculture activities

Further the participation index of all of the 30 activities related to fisheries was carried out to identify the active involvement area of the women. Survey data presented in Table 5 indicates that women participate actively in most of the fisheries and aquaculture activities in the study location. The Table shows that their most significant participation under the post harvesting practices were value addition (3.40), cleaning and grading (3.40) and transporting (2.93). The next important area of participation was managing and looking after the gears and fishing by traditional gears, traps and hooks. It is very interesting to note that fishing in some lakes is done by women exclusively by Chinese dip nets. Nandeesha (2009) in this connection reported that in Manipur, women participation more in fishing than aquaculture, even though they participate in nursery rearing, feeding and exclusively marketing. Higher degree of occasionally participation has been witnessed in marketing fish products (2.87) and marketing of table size fish (2.74). Feeding (2.67), releasing the fish seed in the time of stocking (2.93), selection and purchase of suitable fish seed species $^{-1}(2.63)$ and their transportation (2.68) were reported to be higher side in occasional contribution along with male counterpart. Application of different fishing traps (3.57) and hooks (3.19) managing the gear and crafts (3.47) were also regular features and remarkable.

Interestingly, the Table shows that the non participation of women in any activities related to fisheries is totally nil. They have extended their helping hands in all the activities to their male partners. The grand mean for the participation index, which was found to be 2.72 , is an indication that women in the state participated in almost all the activities in fisheries and aquaculture with their male counterpart and even alone in several areas.

\subsection{Extent of empowerment of rural women through} participation in fisheries activities

Further, the index value of empowerment before and after participation in fisheries was measured and presented in Table 6. A close perusal of the table reveals that there was $35 \%$ gain in empowerment in the study area. The ' $Z$ ' values revealed that, there was significant difference in index values of empowerment of rural women before and after taking up fisheries activity, which clearly revealed the fact that participation in fisheries activity significantly contributed for enhancement in empowerment.

The striking reading of the Table 7 and Figure 1 dealt with significance level of impact of the fisheries activities before and after their participation, which was found by using Wilcoxon signed Rank Test $(Z)$. This gives an idea that decision making ability in family, spending ability, cosmopoliteness, social participation, access to assets and resources of farm women are
Table 5: Participation index of women in different fisheries and aquaculture activities

\begin{tabular}{|c|c|c|c|}
\hline Sl. No. & Aspect & Mean & S.D. \\
\hline A. & Pond preparation & & \\
\hline 1. & Site selection & 2.42 & 0.68 \\
\hline 2. & Designing & 2.20 & 0.71 \\
\hline 3. & Dyke construction and maintenance & 2.39 & 0.69 \\
\hline 4. & Water harvesting & 2.49 & 0.62 \\
\hline 5. & Pond renovation & 2.44 & 0.62 \\
\hline B. & Pre stocking management & & \\
\hline 6. & $\begin{array}{l}\text { Eradication of unwanted fish/weed/ } \\
\text { animals }\end{array}$ & 2.63 & 0.62 \\
\hline 7. & Fertilization of ponds & 2.78 & 0.57 \\
\hline 8. & Liming & 2.47 & 0.67 \\
\hline 9. & Fish seed production & 2.00 & 0.61 \\
\hline C. & Stocking of rearing and grow out pond & & \\
\hline 10. & $\begin{array}{l}\text { Selection and purchase of suitable } \\
\text { fish species }\end{array}$ & 2.63 & 0.52 \\
\hline 11. & Carrying the species & 2.68 & 0.55 \\
\hline 12. & Releasing & 2.93 & 0.70 \\
\hline D. & Post stocking management & & \\
\hline 13. & Feed preparation & 2.44 & 0.62 \\
\hline 14. & Feeding & 2.67 & 0.71 \\
\hline 15. & $\begin{array}{l}\text { Precaution and preventive } \\
\text { measures for disease }\end{array}$ & 2.32 & 0.52 \\
\hline 16. & Pond environment monitoring & 2.56 & 0.58 \\
\hline 17. & Fish health monitoring & 2.47 & 0.66 \\
\hline 18. & Management of common hazards & 2.29 & 0.59 \\
\hline E. & Harvesting & & \\
\hline 19. & Application of proper gear \& crafts & 2.68 & 0.79 \\
\hline 20. & Managing the gear and crafts & 2.90 & 0.69 \\
\hline F. & Post harvesting & & \\
\hline 21. & Cleaning and grading & 3.28 & 0.75 \\
\hline 22. & Preservation & 2.39 & 0.79 \\
\hline 23. & Transport & 2.93 & 0.62 \\
\hline 24. & Value addition & 3.40 & 0.77 \\
\hline G. & Marketing & & \\
\hline 25. & Marketing of table size fish & 2.74 & 0.72 \\
\hline 26. & Marketing of fish products & 2.87 & 0.72 \\
\hline 27. & Marketing of inputs & 2.47 & 0.69 \\
\hline H. & Fishing & & \\
\hline 28. & Managing of gear & 3.47 & 0.73 \\
\hline 29. & Trap & 3.57 & 0.55 \\
\hline 30. & Hook & 3.19 & 0.82 \\
\hline
\end{tabular}

Note: rarely participated $=1.00-1.99$; Occasionally participated 2.00-2.99; regularly participated $=3.00-3.99$ 


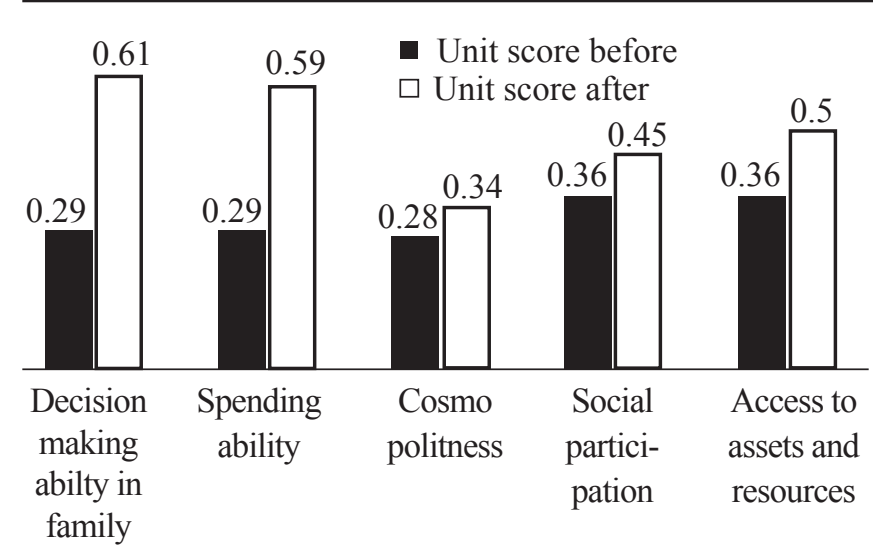

Figure 1: Overall index of impact of fisheries activities in empowering of women

Table 6: Extent of empowerment of rural women through participation in fisheries activities $\mathrm{N}=120$

\begin{tabular}{lccc}
\hline $\begin{array}{l}\text { Index value } \\
\text { (before) }\end{array}$ & $\begin{array}{c}\text { Index value } \\
\text { (after) }\end{array}$ & $\begin{array}{c}\text { Gain in em- } \\
\text { powerment }\end{array}$ & $\begin{array}{c}\text { Wilcoxon signed } \\
\text { rank test (Z) }\end{array}$ \\
\hline 31 & 66 & 35 & $-9.507^{* *}$ \\
\hline
\end{tabular}

Table 7: Scores obtained by the respondent rural women in five dimensions of empowerment before and after their participation in fisheries sector $(\mathrm{N}=120)$

\begin{tabular}{|c|c|c|c|c|c|c|}
\hline \multirow[t]{2}{*}{$\begin{array}{l}\text { Empower- } \\
\text { ment } \\
\text { dimensions }\end{array}$} & \multirow{2}{*}{$\begin{array}{l}\text { Pos- } \\
\text { sible } \\
\text { score } \\
\text { range }\end{array}$} & \multicolumn{2}{|c|}{$\begin{array}{l}\text { Mean and } \\
\text { standard } \\
\text { deviation }\end{array}$} & \multicolumn{2}{|c|}{ Unit score } & \multirow{2}{*}{$\begin{array}{c}\text { Wil- } \\
\text { coxon } \\
\text { signed } \\
\text { rank } \\
\text { test }(\mathrm{Z})\end{array}$} \\
\hline & & Before & After & Before & After & \\
\hline $\begin{array}{l}\text { Decision } \\
\text { making } \\
\text { ability in } \\
\text { family }\end{array}$ & $0-36$ & $\begin{array}{l}10.61 \\
(3.58)\end{array}$ & $\begin{array}{l}21.97 \\
(2.92)\end{array}$ & 0.29 & 0.61 & $-9.528^{* *}$ \\
\hline $\begin{array}{l}\text { Spending } \\
\text { ability }\end{array}$ & $0-30$ & $\begin{array}{c}8.78 \\
(3.73)\end{array}$ & $\begin{array}{l}17.93 \\
(4.70)\end{array}$ & 0.29 & 0.59 & $-9.528^{* *}$ \\
\hline $\begin{array}{l}\text { Cosmo } \\
\text { politeness }\end{array}$ & $0-24$ & $\begin{array}{c}6.62 \\
(3.31)\end{array}$ & $\begin{array}{l}8.15 \\
(3.95)\end{array}$ & 0.28 & 0.34 & $-9.550^{* *}$ \\
\hline $\begin{array}{l}\text { Social par- } \\
\text { ticipation }\end{array}$ & $0-21$ & $\begin{array}{c}7.50 \\
(3.45)\end{array}$ & $\begin{array}{c}9.43 \\
(4.19)\end{array}$ & 0.36 & 0.45 & $-9.536^{* *}$ \\
\hline $\begin{array}{l}\text { Access to } \\
\text { assets and } \\
\text { resources }\end{array}$ & $0-21$ & $\begin{array}{c}7.50 \\
(3.02)\end{array}$ & $\begin{array}{l}10.45 \\
(3.65)\end{array}$ & 0.36 & 0.50 & $-9.530^{* *}$ \\
\hline
\end{tabular}

${ }^{* *} p<0.01$; Figure in parentheses indicating standard deviation

getting improved and increased after participation in fisheries activities and it is highly significant at $(p=0.01)$ level.

\subsection{Constraints perceived by the women in empowerment} through fisheries activities

Constraints as perceived by the respondents which hinder the empowerment process is mentioned in Table 8 . These are very
Table 8: The constraints perceived by the women in empowerment through fisheries activities

\begin{tabular}{llcc}
\hline $\begin{array}{l}\text { Sl. } \\
\text { No. }\end{array}$ & Severity & Rank \\
\hline 1. & $\begin{array}{l}\text { Lack of access and control over } \\
\text { resources such as ownership of land }\end{array}$ & 1.80 & I \\
2. & Low access to credit & 1.74 & II \\
3. & $\begin{array}{l}\text { Lack of confident in technical issues } \\
\text { 4. }\end{array}$ & 1.60 & III \\
& $\begin{array}{l}\text { Lack of women friendly aquaculture } \\
\text { technology mainly in harvesting of }\end{array}$ & 1.50 & IV \\
& &
\end{tabular}
fishes

5. Limited access to training and $\quad 1.42 \quad \mathrm{~V}$ extension services

6. Lack of knowledge and awareness $\quad 1.34 \quad$ VI about improve practices in aquaculture and fishing

7. Lack of recognition $\quad 1.26 \quad$ VII

8. Lack of social mobility because of 1.12 VIII restrictions in the family

9. Women are over burdened with 0.92 IX dual responsibility of managing household and economic activities

10. Confining the role of women to $\quad 0.84 \quad \mathrm{X}$ household activities

11. Doubts regarding the women $\quad 0.46 \quad$ XI capabilities

12. Culture and religious taboos $\quad 0.30 \quad$ XII hindering in participation

important for immediate attention to develop the capability of women for overall development of the nation. The five major constraints according to their priority were "lack of access and control over resources such as ownership of land" (1.80), "low access to credit" (1.74), "lack of confident in technical issues" (1.60), "lack of women friendly aquaculture technology mainly in harvesting of fishes" (1.50) and "limited access to training and extension services" (1.42). The severity of constraints in connection with social issues in women empowerment thorough fisheries activities were perceived as low as majority of women perceived that their role was not confined in household activities (0.84) and they didn't have any doubts regarding the their capabilities to do activities for their empowerment (0.46). It implies that in the state of Manipur the role of women is recognized, and their contribution to the economy is increasing significantly. The cultural traditions provide opportunities and incentives for the equal participation of women in every activity. Unlike in many other parts of India where women's movement and activities are restricted by cultural taboos and folkways, in Manipur such restrictions 
are not commonly seen which is remarkable. The findings of the study support the observation of (Gurumayum et al., 2004). Hasan (2000) also found that there were no traditional and social restrictions in Hinduism related to fish farming.

\section{Conclusion}

Women in the state participated in almost all the activities under fisheries. The extent of gain in empowerment through participation in fisheries activities was $35 \%$ and there was significant difference in index values of empowerment of rural women before and after taking up fisheries activity. No ownership of pond, lower access to credit as well as technical knowhow and lack of women friendly fisheries technologies were perceived as major constraints by the respondents, which need to be resolved with appropriate policy measures.

\section{Acknowledgement}

The authors express their sense of gratitude to the Vice Chancellor, CAU (Imphal) and Dean as well as other faculty members of College of Fisheries, Lembucherra. The authors are also grateful to the respondents of the study.

\section{References}

Ayoade, J., Ibrahim. A.H., Ibrahim, H.Y., 2009. Analysis of women involvement in livestock production in Lafi an area of Nasarawa State, Nigeria. Livestock Research for Rural Development 21(12).

Bharathamma, G.U., 2005. Empowerment of Rural Women through Income Generating Activities in Gadag District on Northern Karnataka. M.Sc. Thesis, Department of Agricultural Extension Education, College of Agriculture, Dharwad University of Agricultural Sciences, Dharwad, 35.

Biswas, T.K., 2002. Women's empowerment and demographic change. Ph.D. Thesis, Department of Statistics, Jahangirnagar University, Dhaka, 105-108.

CIDA(Canadian International Development Agency), 1996. Guide to Gender Sensitive Indicators. CIDA, Canada, 28-30.

Gurumayum, S.D., Devi, G.A., Nandeesha, M.C., 2004. Women participation in fisheries activities in Manipur valley in India with traditional fish based belief and customs. Proceedings of Global Symposium in Gender and Fisheries, Seventh Asian Fisheries Forum, 1-2 December, 2004, Published by the World fish Center, Penang, Malaysia, 149-158.

Hasan, M., 2000. Coastal fishermen communities of Bangladesh: some facts and observations. Grass Roots Voice 3(3), 111-118.

Hossain, S.M.A., 1992. Patterns and determinants of adoption of farm practices: some evidence from Bangladesh. Agricultural Systems 38, 1-15.

Ikiara, M.M., 1999. Sustainability, livelihoods, production and effort supply in a declining fishery: The case of Kenya's Lake Victoria Fisheries. Ph.D. Thesis, University of Amsterdam, 125-126.

Jejeebhoy, S.J., 1995. Women's education, autonomy and reproductive behavior: Experiences from four developing countries. Clarendon Press, Oxford, 28-32.

Kishor, S., 2000. Empowerment of women in egypt and links to the survival and health of the infants. In: Presser, H., Sen, G., (Eds.), Women's Empowerment and Democratic Processes: Moving beyond Cairo. New York: Oxford University Press.

Loomis, C.P., Beegle, J.A., 1957. Rural Sociology: The Strategy of Change. Prentice-Hall, Inc., Cliffs, E., Manimekalai, N., Rajeswari, G., 2000. Empowerment of women through self-help Groups", Margin, 32(4), 74-77.

Nandeesha, M.C., 2009. Enhance women participation in aquaculture to ensure sustainability, Training manual on strengthening capacity of small holder ASEAN aquaculture farmers for competitive and sustainable aquaculture, NACA Secretariat, Bangkok, 133-142.

Nandeesha, M.C., 2001. Help me to help myself: highlights of Phnom Penh seminar on women in fisheries in Indo-China countries, In: Shariff, M., Williams, M.J., Nandeesha, M.C. (Eds.), Report on International Symposium on Women in Asian Fisheries, Available from https://books.google.co.in/ books?isbn $=9832346029$ accessed on 18.04.2014.

Nandeesha, M.C., Hanglomong, H., 1997. Women in fisheries in Indo-China countries. In: Proceedings of the Seminar on Women in Fisheries, Bati Fisheries Station-PADEK, Phnom Penh, Cambodia, 167.

Nash, C.E., Engle, C.R., Crosetti, D., 1987. Women in aquaculture. Proceedings of the ADCP/NORAD Workshop on Women in Aquaculture, Rome, FAO, 13-16 April. FAO Document ADCP/REP/87/28. Rome, FAO, 25.

Rahman, M.H., Naoroze, K., 2007. Women empowerment through participation in aquaculture: experience of a large-scale technology demonstration project in Bangladesh, Journal of Social Science 3(4), 164-171.

Stromquist, N.P., 1995. The theoretical and practical bases for empowerment. In: Medel-Anonuevo, C. (Ed.). Women, education and empowerment: pathways towards autonomy. Report of the International Seminar Held at UIE, Hamburg, Germany, UNESCO, Paris, 28-32.

Suresh, K., 2008. Impact of micro finance on empowerment of rural women- a case study of dairy enterprise in the tank management project area of North Karnataka. M.Sc. Thesis (Unpublished), Department of Agriculture Economics, college of Agriculture, University of Agricultural Science, Dhaward, 48-49.

World Bank Report, 1986. Poverty and hunger: issues and options for food security in developing countries. World Bank Report, Washington D.C., 39. 